\title{
Effects of disputes and easement violations on the cost- effectiveness of land conservation
}

Richard Schuster, Peter Arcese

Conservation initiatives to protect and restore valued species communities in humandominated landscapes face challenges linked to their potential costs. Conservation easements on private land may represent a cost-effective alternative to land purchase, but long-term costs to monitor and enforce easements, or defend legal challenges, remain uncertain. We explored the cost-effectiveness of conservation easements, defined here as the fraction of the high-biodiversity landscape potentially protected via investment in easements versus land purchase. We show that easement violation and dispute rates substantially affect the estimated long-term cost-effectiveness of an easement versus land purchase strategy. Our results suggest that conservation easements can outperform land purchase as a strategy to protect biodiversity as long as the rate of disputes and legal challenges is low, pointing to a critical need for monitoring data to reduce costs and maximize the value of conservation investments. 
1 Effects of disputes and easement violations on the cost-effectiveness of land conservation

2

3 Richard Schuster ${ }^{\mathrm{a}^{*}}$, Peter Arcese ${ }^{\mathrm{a}}$

4

$5 \quad$ a Department of Forest and Conservation Sciences, 2424 Main Mall, University of British

6 Columbia, Vancouver V6T 1 Z4 Canada

7

8 * Corresponding author. Tel.: +1 604822 1256; fax: +1 6048229102.

9 E-mail address: mail@richard-schuster.com

10

11 Running title: Cost-effectiveness of easements 


\section{Abstract}

13 Conservation initiatives to protect and restore valued species communities in human-dominated

14 landscapes face challenges linked to their potential costs. Conservation easements on private

15 land may represent a cost-effective alternative to land purchase, but long-term costs to monitor

16 and enforce easements, or defend legal challenges, remain uncertain. We explored the cost-

17 effectiveness of conservation easements, defined here as the fraction of the high-biodiversity

18 landscape potentially protected via investment in easements versus land purchase. We show that

19 easement violation and dispute rates substantially affect the estimated long-term cost-

20 effectiveness of an easement versus land purchase strategy. Our results suggest that conservation

21 easements can outperform land purchase as a strategy to protect biodiversity as long as the rate

22 of disputes and legal challenges is low, pointing to a critical need for monitoring data to reduce

23 costs and maximize the value of conservation investments. 


\section{INTRODUCTION}

25

Despite an urgent need to develop mechanisms to promote biodiversity conservation (Ehrlich and Pringle 2008, Butchart et al. 2010, Bayon and Jenkins 2010, Estes et al. 2011), developing such mechanisms in human-dominated landscapes, where private ownership prevails and the cost of land purchase and opportunity costs of conservation can be substantial, is challenging (Naidoo et al. 2006, Wunder 2007). One potentially cost-effective route to conservation in such areas may be to promote private land conservation easements or covenants that prohibit land use changes likely to reduce conservation values in exchange for monetary or other compensation (Merenlender et al. 2004, Knight et al. 2011). Advantages of easements include their low initial cost compared to land purchase (Pence et al. 2003) and their ability to facilitate voluntary conservation with landowners wishing to retain title (Langholz and Lassoie 2001, Winter et al. 2005, Knight et al. 2010, Selinske et al. 2015). Easements have thus gained global attention as conservation tools (Fishburn et al. 2009, Gordon et al. 2011). For the purposes of this study we define conservation easements, also called conservation covenants in e.g. Canada and Australia, as voluntary agreements between easement holders, typically land trusts or government agencies, and private landowners (Rissman et al. 2007). Easement holders acquire and hold certain property rights in order to restrict land use, in most cases permanently (Gustanski and Squires 2000, Owley 2004). In return private landowners may receive a payment and/or reduction in taxes (Byers and Ponte 2005).

The factors affecting the cost-effectiveness of easement versus land purchase strategies for biodiversity conservation remain unclear (Armsworth and Sanchirico 2008, Fishburn et al. 
47 2009), but it is reasonable to assume that factors like the knowledge and willingness of

48 landholders to manage their easements, as well as the types of ecosystems they are trying to

49 manage would be part of this (Selinske et al. 2015). Because the long-term costs of monitoring,

50 enforcing and legally defending easements is unknown, simple comparisons of land purchase to

51 easements as approaches to conservation could overestimate the cost-effectiveness of easements

52 (Copeland et al. 2013, Morzaria-Luna et al. 2014). Thus representing these uncertainties as

53 potential risks to easement holders should help estimate the cost-effectiveness of these alternate

54 approaches to conservation (Byers and Ponte 2005, Knight et al. 2010, Rissman and Butsic

55 2011). The cost-effectiveness of easements is likely related to the extent of monitoring, which in

56 itself is likely to be a substantial influence on the identification of easement issues, and the extent

57 of recording those issues would influence how it becomes a violation or escalates to a dispute.

58 Despite some effort to address financial risk, such as the 'Conservation Defense Liability

59 Insurance' for easement holders in the United States (Land Trust Alliance 2009), detailed studies

60 are lacking and it remains unknown whether easements offer similar levels of biodiversity

61 protection as compared to land purchase (Merenlender et al. 2004, Fishburn et al. 2009), despite

62 increased demand for easement like agreements from landholders (Fitzsimons and Carr 2014).

63 These uncertainties highlight the need for a theoretical framework to evaluate the cost-

64 effectiveness of biodiversity conservation by establishing conservation easements versus fee

65 simple land purchase.

66

67 We developed a simple theoretical framework to explore conservation outcomes by defining and

68 estimating the uncertainties described above, and using biodiversity and property values to

69 compare the total cost and effectiveness of land purchase versus conservation easements as 
70 strategies to protect critically endangered Old Forest and Savannah habitats of the Georgia Basin

71 of south-western British Columbia, where $<20 \%$ of the landscape is owned by governments and

72 only $9 \%$ allocated to conservation. Specifically, we asked two questions about the long-term

73 (100 year) cost and biodiversity value of easement versus land purchase strategies: 1) how will

74 dispute rate influence the cost-effectiveness of each approach, and 2) assuming that violations

75 reduce the area of easements under conservation (e.g. Smith 2009), what is the total area of the

76 high-biodiversity landscape likely to be protected given alternative investment in easements

77 versus land purchase. Here we define dispute as an attempt to or the active breach of the

78 easement conditions by a landowner, such as illegal logging or attempting to add a new structure.

79 As a consequence this would lead to a reduction of habitat protected under the easement. We

80 define a violation as a breach of easement conditions resulting in a partial loss of the easement

81 area, where the magnitude of the loss is dependent on the dispute cost. To answer these questions

82 we used occupancy maps for 47 bird species and expert elicitation to map high-biodiversity

83 landscapes and assessed land value to represent cost. We then contrasted the land purchase

84 scenarios of Schuster et al. (2014), aimed at maximizing biodiversity conservation, to scenarios

85 employing easements but subject to a range of assumptions about dispute rate and cost. Schuster

86 et al. (2014) identified conservation networks based on fee-simple land purchase, designed to

87 maximize avian biodiversity in Old Forest and Savannah habitats and found that using beta-

88 diversity was the most cost-effective way to reach conservation targets. Overall, we offer a novel

89 theoretical framework for evaluating land acquisition for biodiversity conservation and highlight

90 the need for empirical analyses to estimate the long-term costs of monitoring and potential costs

91 and rate of legal challenges.

92 
114 urgently needed.

\section{$\underline{\text { Ethics Statement }}$} animals.

\section{$\underline{\text { Study region }}$}

\section{MATERIALS AND METHODS}

Permits or permission for the use of bird point count locations were obtained from Parks Canada (locations in National Park Reserves), private land owners (locations on private land), or did not require specific permission as they occurred on public right of ways (e.g., roadsides, regional parks). As private land owners did not want their information posted publically please contact the authors for contact details. The field studies did not involve endangered or protected species. This study did not require approval from an Animal Care and Use Committee because it was a non-invasive observational field study, and did not involve the capture and handling of wild

We studied a $2520 \mathrm{~km}^{2}$ portion of the Coastal Douglas Fir (CDF) ecological zone of the Georgia Basin of British Columbia (BC), Canada (Appendix S1 in Supporting Information). The CDF includes a critically endangered but diverse suite of old forest and savannah plant and animal communities endemic to the region but is $\geq 60 \%$ converted to human use (Austin et al. 2008), and $\leq 0.3 \%$ of old forest ( $>250$ years) (MES 2008) and $\leq 10 \%$ of oak woodlands extant prior to European contact remain (Lea 2006), both of which provide habitat for 117 species at risk of extirpation (Austin et al. 2008). Because regional, provincial and federal authorities own $<20 \%$ of the region and only $\sim 9 \%$ is already conserved, cost-efficient routes to conservation are 
115 Prior to European colonization the CDF occurred as uneven-aged forest (often $>300$ years old)

116 dissected by shallow and deep-soil meadow and woodland communities (Meidinger and Pojar

117 1991, Mosseler et al. 2003) maintained in part by aboriginal land management practices to

118 enhance hunting opportunities and root and fruit harvests (MacDougall et al. 2004, Dunwiddie

119 and Bakker 2011, McCune et al. 2013, Turner 2014). Oak woodland and savannah community

120 distributions are predicted to shift under future climate conditions, and only a small fraction of

121 the current protected areas have the potential to accommodate this shift (Pellatt et al. 2012).

122 There is large land use heterogeneity within the region and the potential for humans to directly or

123 indirectly affect native species richness (Gonzales and Arcese 2008, Martin et al. 2011, Bennett

124 et al. 2012, Schuster and Arcese 2013). Several land trusts in the region, such as The Nature

125 Trust of British Columbia ( http://www.naturetrust.bc.ca) and the Islands Trust Fund

126 (http://www.islandstrustfund.bc.ca) hold conservation easement. Protected areas in the region

127 range from 0.01 to 5,830 acres $($ mean $=81)$ in size and span whole islands of up to 1300 acres in

128 size, over small parcels in urban areas to holdings in remote (island) locations. In general, real

129 estate in the region is very expensive with an average cost per acre of $\$ 2.1 \mathrm{M}$, but there are

130 affordable properties in non-urban areas ( $8 \%$ of all properties cost less than $\$ 100,000$ per acre).

132 Land purchase cost scenario

133 We built on Schuster et al. (2014) to identify conservation networks based on fee-simple land

134 purchase and designed to maximize avian biodiversity in Old Forest and Savannah habitats. To

135 do so, we developed distribution models for 47 birds based on 25 remote-sensed predictor

136 variables and incorporating imperfect detectability (Mackenzie et al. 2002) to create composite

137 community scores (Schuster and Arcese 2013). To consolidate focal species occurrence 
138 predictions into an index of Old Forest and Savannah community association, we combined focal

139 species occurrence predictions using expert elicitation to rank the likelihood of observing 47

140 species in 10 focal habitat types using photographic and text descriptions of herbaceous, shrub,

141 woodland, wetland, four forest types (pole, young, mature and old), and 2 human-dominated

142 habitats (rural, urban), to create two community metrics indicating Old Forest and Savannah

143 (SAV) habitats (Schuster et al. 2014). These metrics match our goals given the region's history

144 and focus on Old Forest and Savannah community conservation (see 'Study region').

145 Specifically, each species contributed to the cumulative Old Forest or Savannah community

146 score, weighted by its expert opinion score for the given sub-type, summed across species to

147 create community specific association scores from 0 to 1 , and corresponding to none versus all

148 members of the community expected to be present. We then combined Old Forest and Savannah

149 community scores to create a beta-diversity metric to identify heterogeneous landscapes likely to

150 maximize the occurrence of both target communities, as previous work has shown that using a

151 beta-diversity metric results in the most cost-effective reserve design solutions (Schuster et al.

152 2014).

153

154 Cadastral data was used to identify properties and 2012 assessments to represent property cost.

155 We then used the systematic reserve design software Marxan (Ball et al. 2009) to prioritize

156 properties $(n=193,623)$ by the beta-diversity metric for inclusion in conservation networks to

157 protect $20 \%$ of the total beta-diversity scores (Schuster et al. 2014). We retained 100 Marxan

158 solutions to estimate variability in spatial network configuration and cost. As acquired properties

159 require investments in staff, infrastructure and land management over time, it has been suggested

160 that land trust use endowments to fund these costs in the long term (Armsworth et al. 2015). 
161 Most large land management organizations in the region have recently adopted a policy of

162 raising funds for each land purchase that equal $15 \%$ of purchase value, and put those funds in

163 trust (The Nature Trust of British Columbia, pers. comm.). To account for this we added $15 \%$ to

164 purchase prices for each property in a conservation network. Disputes that effectively increase

165 land purchase costs are reported from parts of the US (Rissman and Butsic 2011), but so far none

166 have been reported in our study region; thus we excluded dispute costs from our land purchase

167 scenario. This decision was based on an informal survey conducted at The Nature Trust of

168 British Columbia, which serves as the curator of the Land Trust conservation land database,

169 which yielded no reported disputes. Another potential issue for the long term conservation of

170 biodiversity by protected areas is downgrading, downsizing and degazettment (PADDD) (Mascia

171 and Pailler 2011). However, in the study region no cases of PADDD have been reported yet

172 (Islands Trust Fund, pers. comm.) and the Best Practices for Land Trusts in Canada requires

173 Land Trusts to monitor protected lands and manage damages (Canadian Land Trust Alliance

174 2005), which can be dealt with via the endowed management funds mentioned above if they do 175 occur.

176

177 Easement cost metrics and assumptions

178 All properties selected in land purchase Marxan solutions were used as candidate easements

179 under the assumption of willing current owners for both land purchase and easement

180 participation. We did not estimate change in land value given easements as there is no consensus

181 on magnitude or direction (Anderson and Weinhold 2008). Easement costs used here reflect the

182 experience of The Nature Trust of British Columbia and Islands Trust Fund and published

183 examples (Main et al. 1999, Parker 2004). We compiled estimates of fixed easement costs 
184 including: legal, financial advice, registration and endowment fees, as well as scalable costs of

185 surveys and appraisal (Table 1). Land managers identified reoccurring costs of annual

186 monitoring and staff time to address land owner requests (Table 1). All costs were estimated in

187 present day Canadian dollars, because the alternative use of a discount rate equal to the inflation

188 rate for costs incurred over time, and then reporting in future dollar values is highly sensitive to

189 the discount rate, adding substantial uncertainty on future dollar amounts (Arrow et al. 2013).

190

191 Conservation easement scenarios

192 We calculated the cost-effectiveness of alternate scenarios as the fraction of the high-biodiversity

193 landscape protected, divided by the total reserve network cost for each scenario (Wilson et al.

194 2007) and then standardized this value by the cost of land purchase for comparisons. We

195 followed Rissman and Butsic (2011) to estimate the distribution of dispute costs and fitted a cost

196 profile bound between $\$ 1000$ and $\$ 400,000$ following the power function cost $[\$]=4845.78 *$

197 disputes $^{-0.701}$. We also explored cost profiles including dispute costs over $\$ 400 \mathrm{k}$ using a truncated

198 normal distribution where the left tail was cut off. As the starting point or mean of that

199 distribution we used $\$ 400 \mathrm{k}$. We chose a very wide standard error $(\$ 1 \mathrm{M})$ to allow for dispute

200 costs to rise substantially above $\$ 400 \mathrm{k}$, and $1 \%$ probability of those costs arising but found

201 similar results, and thus restricted our analysis to published values. To find the easement dispute

202 rate that caused the cost effectiveness of land purchase to exceed that of easements, we used

203 dispute rates of $0.028,0.28$ and $2.8 \%$ of easements per year. Rissman and Butsic (2011)

204 surveyed 205 land trusts to report that they experienced about 2.8 disputes per year, but because

205 they did not record the total number of easements represented we could not estimate dispute rates 206 precisely. 
208 Typically, if an easement is held by an organization, and a landowner breaks the easement in a

209 way that reduces habitat, such as via illegal logging, the easement holder must sue for damages.

210 There was no data on disputes available for the study area, but a 1999 Land Trust Alliance

211 survey found that out of 7,400 conservation easements 498 violations were reported, 383 of

212 which were minor and got resolved without significant commitment of resources. 115 were

213 major violations, but 94 were resolved without litigation and 21 cases resulted in lawsuits

214 (Danskin 2000). Suits can be costly but if the organization wins, which happened in all but one

215 case reported by Danskin (2000), one of two things may happen. 1. landowners pay restitution to

216 the organization or 2. are forced to restore the damage. We therefore included two types of

217 disputes in our models: pre-emptive enforcement (PE), and damage enforcement (DE). PE

218 occurs when a landowner attempts to do something disallowed by the easement, such as adding

219 as new structure, and the easement holder sues to stop them. The outcome here may be little or

220 no habitat change but a large cost to the easement holder to enforce the easement. DE involves

221 activities that have already taken place, such as illegal logging. In this case, easement holders

222 may sue successfully for compensation of their loss, thus with no monetary cost to the dispute,

223 but still suffer habitat damage and biodiversity decline.

225 In each year of our simulation, easements suffered disputes at rates assumed above and, given a

226 dispute, were randomly assigned to either the PE or DE dispute model. In the PE case an

227 easement was assigned a randomly drawn dispute cost that contributed to the total cost of

228 easement scenarios. To quantify the effect of disputes on biodiversity values in a DE case we

229 assumed that biodiversity loss followed the same distribution as dispute cost, bounded between 0 
230 and $100 \%$, which was then used to reduce the disputed easement's beta diversity metric. In the

231 absence of empirical study, we also relaxed that assumption by allowing variation in biodiversity

232 loss to follow a normal distribution around the estimate $(\mathrm{SD}=5 \%$ of total biodiversity loss

233 possible). All analyses were conducted using R v.3.2.0 (R Core Team 2015) and the analysis

234 script can be found in Appendix S1. We have also provided a reproducible example of the entire

235 analysis on GitHub (https://github.com/yeronimo/Easement_cost-effectiveness or

236 http://dx.doi.org/10.5281/zenodo.21144).

237

238

239 RESULTS

240 Given a goal of protecting $20 \%$ of the high-biodiversity landscape, land purchase scenarios

241 protected a mean of $370 \mathrm{~km}^{2}\left(\right.$ range $\left.=365-374 \mathrm{~km}^{2}\right)$ at a mean cost of $\$ 457 \mathrm{M}($ range $=\$ 441-$

$242470 \mathrm{M})$ (Figure 1a). In comparison, the cost of an equivalent area under conservation easements

243 averaged $\$ 43.9 \mathrm{M}$ in year $1($ range $=\$ 42.6-45.0 \mathrm{M})$ and $\$ 162 \mathrm{M}$ cumulatively to year 100 (range

$244=\$ 157-166 \mathrm{M} ;$ Figure 1a), representing a $65 \%$ reduction in cost compared to land purchase.

245 Including dispute rates of 0.028 and $0.28 \%$ increased long term costs in easement scenarios by

2460.5 and $11 \%$, respectively (Figure 1a). However, with $2.8 \%$ of easements experiencing disputes

247 annually, network cost increased up to $219 \%($ mean $=\$ 355 \mathrm{M}$, range $=\$ 339-382 \mathrm{M})$, but this

248 was still below the cost of land purchase (Figure 1a). Table 2 summarizes our overall results.

250 Baseline scenarios in the absence of disputes aimed to protect $20 \%$ of the high-biodiversity

251 landscape. However, under the assumption that disputes cause biodiversity loss, a dispute rate of

$2520.028 \%$ reduced the area effectively conserved after 100 years by $0.36 \%$ (range $=0.05-0.83 \%$ ) 
253 compared to baseline (Figure 1b). In contrast, an intermediate dispute rate $(0.28 \%)$ returned a

254 mean reduction of $3.71 \%$ (range $=2.19-5.18 \%)$, and a high dispute rate $(2.8 \%)$ returned a mean

255 reduction of $31.73 \%$ (range $=28.94-36.1 \%$; Figure $1 b)$.

256

257 Given our results above, the cost-effectiveness of conservation easement versus land purchase

258 scenarios was $2.8-3.3$ times higher after 100 years (Figure 2). However, a high annual dispute

259 rate of $2.8 \%$ caused the cost-effectiveness of easement scenarios to approach that of land

260 purchase (Figure 2).

261

262

263 DISCUSSION

264 We show that easement violations and disputes can substantially affect the long-term cost-

265 effectiveness of conservation strategies employing easements or land purchase to protect high-

266 biodiversity landscapes. In particular, in terms of cost-effectiveness land purchase performed as

267 well as an easement approach to protection when dispute rates were high, in part because

268 disputes often co-occur with biodiversity loss (Figure 1b, 2). These results point out critical

269 uncertainties about the cost-effectiveness of conservation easements and potential liabilities to

270 easement holders. However, the low initial cost of conservation easements as compared to land

271 purchase suggest that as long as disputes are rare, easements should outperform land purchase as

272 a cost-effective tool for biodiversity conservation (Figure 2). We now develop these points in

273 light of literature on land acquisition and easements and identify several remaining uncertainties. 274

275 Easement dispute rate 
276 We found that the cost-effectiveness of easements versus land purchase depend primarily on 277 easement dispute rate (Figure 2), indicating that minimizing dispute rate should be a key goal.

278 However, the paucity of published data on the frequency and cost of disputes (Byers and Ponte 279 2005, Rissman and Butsic 2011) points to an urgent need to formalize the experience of 280 conservation organizations to identify pitfalls and reduce dispute rate in future. A survey

281 conducted by the Land Trust Alliance showed that dispute rate increases with the number of 282 successive owners of easement properties (Jay 2014). If true, some existing easements may 283 represent unrecognized risk to holders that should be remedied before titles transfer.

285 Dispute costs

286 We adopted a dispute cost profile based on a survey of 205 land trusts, but including substantial 287 uncertainty and a maximum dispute cost of $\$ 400 \mathrm{k}$ (Rissman and Butsic 2011), but are aware of 288 examples with potentially much higher costs. Although we used an inverse dispute cost profile in 289 our simulations, the risk of very large costs remains an uncertain risk to all easement holders.

290 Empirical data are therefore needed to characterize cost profiles and facilitate realistic analyses

291 (Boyd et al. 2000, Game et al. 2013). Although more complex cost profiles than we used can be

292 imagined, they remain speculative in the absence of data and we observed modest variation in

293 dispute costs had little influence on our results. We used pre-emptive enforcement (PE) and

294 damage enforcement (DE) to represent possible legal scenarios here. PE occurs when a

295 landowner attempts to do something disallowed by the easement, such as adding as new

296 structure, and the easement holder sues to stop them. The outcome here may be little or no

297 habitat change but a large cost to the easement holder to enforce the easement. DE involves

298 activities that have already taken place, such as illegal logging. In this case, easement holders 
299 may sue successfully for compensation of their loss, thus with no monetary cost to the dispute,

300 but still suffer habitat damage and biodiversity decline. We believe PE and DE represent

301 reasonable approximations of the most common dispute scenarios, but acknowledge different

302 scenarios such as DE without compensation would be possible as well, but less likely.

303

304

305 Biodiversity loss and easement dispute

306 The potential for biodiversity loss when easements are violated is also uncertain. We found that

307 at intermediate dispute rates, the area of high-biodiversity landscape conserved declined $3 \%$ after

308100 years (Figure 2). However, at higher dispute rates nearly a third of the conserved landscape

309 was lost, assuming disputes involve the loss of protected elements or site integrity (Smith 2009).

310 Although our assumption that biodiversity loss and dispute cost vary directly remains untested,

311 we suggest it is a reasonable initial assumption given that easement violations often involve land

312 clearing, road building or new structures likely to reduce biodiversity value (Danskin 2000).

313 Thus, easement disputes have the potential to add management cost and facilitate biodiversity

314 loss, suggesting these potential costs must be considered when comparing conservation

315 strategies.

316

317 Conclusion

318 We offer a theoretical approach to compare the cost-effectiveness of conservation easements vs.

319 land purchase as alternative approaches to biodiversity conservation. Our results indicate that

320 over the long-term, the cost-effectiveness of conservation easements should outperform land

321 purchase as a strategy to protect habitat as long as the rate of disputes and legal challenges to 
322 easements remain low. Anecdotal evidence from land trusts suggests that the risk of disputes

323 depends a lot on how the covenants were written, and they have and are continuing to get better.

324 We think that improved legal wording will reduce risk of easement failure over the long-term

325 and could help conservation organizations to save guard against legal disputes. Recommended

326 actions to improve the comparison of land purchase and easements as approaches to biodiversity

327 protection include estimating more precisely i) easement dispute rates and cost profiles over

328 time, and ii) biodiversity loss given a dispute. Our findings should apply generally to landscapes

329 with high rates of private ownership and human impact, such as the Georgia Basin of western

330 North America.

331

332 Acknowledgements

333 We thank the Conservation Decisions Team (CSIRO, Australia) for hosting RS, S. Gergel, R.

334 Germain and V. LeMay and four anonymous reviewers for comments on an earlier version of

335 this manuscript, The Nature Trust of British Columbia, Islands Trust and A. Rissman for input

336 on the easement process and costs.

337

338

339

340 Supporting Information

341 Additional Supporting Information may be found in the online version of this article:

342

343 Appendix S1. A figure of the Georgia Basin of British Columbia, Canada, highlighting the study 344 region as well as the $\mathrm{R}$ script that we used for our analysis and simulations. 
346 We have also provided a reproducible example of the entire analysis on GitHub

347 (https://github.com/yeronimo/Easement_cost-effectiveness or

348 http://dx.doi.org/10.5281/zenodo.21144). 


\section{References}

350

351

352

353

354

355

356

357

358

359

360

361

362

363

364

365

366

367

368

369

370

371

372

373

374

375

376

377

378

379

380

381

Anderson, K., and D. Weinhold. 2008. Valuing future development rights: the costs of conservation easements. Ecological Economics 68:437-446.

Armsworth, P. R., E. R. Larson, S. T. Jackson, D. F. Sax, P. Simonin, B. Blossey, N. Green, M. L. Klein, L. Lester, T. H. Ricketts, and others. 2015. Are conservation organizations configured for effective adaptation to global change? Frontiers in Ecology and the Environment 13:163-169.

Armsworth, P. R., and J. N. Sanchirico. 2008. The effectiveness of buying easements as a conservation strategy. Conservation Letters 1:182-189.

Arrow, K., M. Cropper, C. Gollier, B. Groom, G. Heal, R. Newell, W. Nordhaus, R. Pindyck, W. Pizer, P. Portney, and others. 2013. Determining benefits and costs for future generations. Science 341:349-350.

Austin, M. A., D. A. Buffett, D. J. Nicolson, G. G. E. Scudder, and V. Stevens. 2008. Taking Nature's Pulse: The Status of Biodiversity in British Columbia. Biodiversity BC, Victoria, $\mathrm{BC}$.

Ball, I. R., H. P. Possingham, and M. E. Watts. 2009. Marxan and relatives: Software for spatial conservation prioritisation. Pages 185-195 in A. Moilanen, K. Wilson, and H. P. Possingham, editors. Spatial conservation prioritisation quantitative methods and computational tools. Oxford University Press, Oxford.

Bayon, R., and M. Jenkins. 2010. The business of biodiversity. Nature 466:184-5.

Bennett, J. R., M. Vellend, P. L. Lilley, W. K. Cornwell, and P. Arcese. 2012. Abundance, rarity and invasion debt among exotic species in a patchy ecosystem. Biological Invasions 15:707-716.

Boyd, J., K. Caballero, and R. D. Simpson. 2000. Law and economics of habitat conservation: Lessons from an analysis of easement acquisitions, the. Stan. Envtl. LJ 19:209.

Butchart, S. H. M., M. Walpole, B. Collen, A. van Strien, J. P. W. Scharlemann, R. E. A. Almond, J. E. M. Baillie, B. Bomhard, C. Brown, J. Bruno, K. E. Carpenter, G. M. Carr, J. Chanson, A. M. Chenery, J. Csirke, N. C. Davidson, F. Dentener, M. Foster, A. Galli, J. N. Galloway, P. Genovesi, R. D. Gregory, M. Hockings, V. Kapos, J.-F. Lamarque, F. Leverington, J. Loh, M. A. McGeoch, L. McRae, A. Minasyan, M. Hernández Morcillo, T. E. E. Oldfield, D. Pauly, S. Quader, C. Revenga, J. R. Sauer, B. Skolnik, D. Spear, D. Stanwell-Smith, S. N. Stuart, A. Symes, M. Tierney, T. D. Tyrrell, J.-C. Vié, and R. Watson. 2010. Global biodiversity: indicators of recent declines. Science 328:1164-8. 
382

383

384

385

386

387

388

389

390

391

392

393

394

395

396

397

398

399

400

401

402

403

404

405

406

407

408

409

410

411

412

413

414

415

Byers, E., and K. M. Ponte. 2005. The conservation easement handbook. Land Trust Alliance Washington, DC.

Canadian Land Trust Alliance. 2005. Canadian Land Trust Standards and Practices. Available at: http://tabc.ca.

Copeland, H. E., A. Pocewicz, D. E. Naugle, T. Griffiths, D. Keinath, J. Evans, and J. Platt. 2013. Measuring the effectiveness of conservation: A novel framework to quantify the benefits of sage-grouse conservation policy and easements in Wyoming. PloS one 8:e67261.

Danskin, M. 2000. Conservation Easement Violations: Results from a Study of Land Trusts. Land Trust Alliance Exchange 19.

Dunwiddie, P. W., and J. D. Bakker. 2011. The future of restoration and management of prairieoak ecosystems in the Pacific Northwest. Northwest Science 85:83-92.

Ehrlich, P. R., and R. M. Pringle. 2008. Where does biodiversity go from here? A grim businessas-usual forecast and a hopeful portfolio of partial solutions. Proceedings of the National Academy of Sciences 105:11579-11586.

Estes, J. A., J. Terborgh, J. S. Brashares, M. E. Power, J. Berger, W. J. Bond, S. R. Carpenter, T. E. Essington, R. D. Holt, J. B. C. Jackson, R. J. Marquis, L. Oksanen, T. Oksanen, R. T. Paine, E. K. Pikitch, W. J. Ripple, S. A. Sandin, M. Scheffer, T. W. Schoener, J. B. Shurin, A. R. E. Sinclair, M. E. Soulé, R. Virtanen, and D. A. Wardle. 2011. Trophic downgrading of planet Earth. Science 333:301-6.

Fishburn, I. S., P. Kareiva, K. J. Gaston, and P. R. Armsworth. 2009. The Growth of Easements as a Conservation Tool. PLoS ONE 4:6.

Fitzsimons, J. A., and C. Ben Carr. 2014. Conservation Covenants on Private Land: Issues with Measuring and Achieving Biodiversity Outcomes in Australia. Environmental management 54:606-616.

Game, E. T., J. A. Fitzsimons, G. Lipsett-Moore, and E. McDonald-Madden. 2013. Subjective risk assessment for planning conservation projects. Environmental Research Letters 8:45027-45038.

Gonzales, E. K., and P. Arcese. 2008. Herbivory more limiting than competition on early and established native plants in an invaded meadow. Ecology 89:3282-3289.

Gordon, A., W. T. Langford, M. D. White, J. A. Todd, and L. Bastin. 2011. Modelling trade offs between public and private conservation policies. Biological Conservation 144:558-566.

Gustanski, J. A., and R. H. Squires. 2000. Protecting the land: conservation easements past, present, and future. Island Press. 
416 Jay, J. E. 2014. Enforcing Perpetual Conservation Easements Against Third-Party Violators. 417 UCLA Journal of Environmental Law \& Policy 32:3-14.

418 Knight, A. ., R. M. Cowling, M. Difford, and B. M. Campbell. 2010. Mapping Human and 419 Social Dimensions of Conservation Opportunity for the Scheduling of Conservation Action $420 \quad$ on Private Land. Conservation Biology 24:1348-1358.

421

422

423

424

425

426

427

428

429

430

431

432

433

434

435

436

437

438

439

440

441 442

443

444

445

446 447

Knight, A. T., H. S. Grantham, R. J. Smith, G. K. McGregor, H. P. Possingham, and R. M. Cowling. 2011. Land managers' willingness-to-sell defines conservation opportunity for protected area expansion. Biological Conservation 144:2623-2630.

Land Trust Alliance. 2009. Exploring Conservation Defense Insurance: Considerations for Board Members. Washington, DC.

Langholz, J. A., and J. P. Lassoie. 2001. Perils and Promise of Privately Owned Protected Areas. BioScience 51:1079-1085.

Lea, T. 2006. Historical Garry oak ecosystems of Vancouver Island, British Columbia, preEuropean contact to the present. Davidsonia 17:34-50.

MacDougall, A. S., B. R. Beckwith, and C. Y. Maslovat. 2004. Defining conservation strategies with historical perspectives: a case study from a degraded oak grassland ecosystem. Conservation Biology 18:455-465.

Mackenzie, D. I., J. D. Nichols, G. B. Lachman, S. J. Droege, J. A. Royle, and C. A. Langtimm. 2002. Estimating site occupancy rates when detection probabilities are less than one. Ecology 83:2248-2255.

Main, M. B., F. M. Roka, and R. F. Noss. 1999. Evaluating Costs of Conservation. Conservation Biology 13:1262-1272.

Martin, T. G., P. Arcese, and N. Scheerder. 2011. Browsing down our natural heritage: Deer impacts on vegetation structure and songbird populations across an island archipelago. Biological Conservation 144:459-469.

Mascia, M. B., and S. Pailler. 2011. Protected area downgrading, downsizing, and degazettement (PADDD) and its conservation implications. Conservation Letters 4:9-20.

McCune, J. L., M. G. Pellatt, and M. Vellend. 2013. Multidisciplinary synthesis of long-term human--ecosystem interactions: A perspective from the Garry oak ecosystem of British Columbia. Biological Conservation 166:293-300.

Meidinger, D., and J. Pojar. 1991. Ecosystems of British Columbia. British Columbia Ministry of Forests, Victoria, BC. 
Merenlender, A. M., L. Huntsinger, G. Guthey, and S. K. Fairfax. 2004. Land trusts and conservation easements: Who is conserving what for whom? Conservation Biology 18:6576.

MES. 2008. Terrestrial Ecosystem Mapping of the Coastal Douglas-Fir Biogeoclimatic Zone. Madrone Environmental Services LTD., Duncan, BC. Mandrone Environmental Services LTD., Duncan, BC.

Morzaria-Luna, H. N., A. Castillo-López, G. D. Danemann, and P. Turk-Boyer. 2014. Conservation strategies for coastal wetlands in the Gulf of California, Mexico. Wetlands Ecology and Management 22:267-288.

Mosseler, A., I. Thompson, and B. A. Pendrel. 2003. Overview of old-growth forests in Canada from a science perspective. Environmental Reviews 11:S1-S7.

Naidoo, R., A. Balmford, P. J. Ferraro, S. Polasky, T. H. Ricketts, and M. Rouget. 2006. Integrating economic costs into conservation planning. Trends in ecology \& evolution 21:681-7.

Owley, J. 2004. Exacted conservation easements: the hard case of endangered species protection. Journal of Environmental Law \& Litigation 19.

Parker, D. P. 2004. Land trusts and the choice to conserve land with full ownership or conservation easements. Natural Resources Journal 44:483-518.

Pellatt, M. G., S. J. Goring, K. M. Bodtker, and A. J. Cannon. 2012. Using a down-scaled bioclimate envelope model to determine long-term temporal connectivity of Garry oak (Quercus garryana) habitat in western North America: implications for protected area planning. Environmental management 49:802-815.

Pence, G. Q. K., M. A. Botha, and J. K. Turpie. 2003. Evaluating combinations of on-and offreserve conservation strategies for the Agulhas Plain, South Africa: a financial perspective. Biological Conservation 112:253-273.

R Core Team. 2015. R: A Language and Environment for Statistical Computing. R Foundation for Statistical Computing, Vienna, Austria.

Rissman, A. R., and V. Butsic. 2011. Land trust defense and enforcement of conserved areas. Conservation Letters 4:31-37.

Rissman, A. R., L. Lozier, T. Comendant, P. Kareiva, J. M. Kiesecker, M. R. Shaw, and A. M. Merenlender. 2007. Conservation easements: biodiversity protection and private use. Conservation Biology 21:709-718.

Schuster, R., and P. Arcese. 2013. Using bird species community occurrence to prioritize forests for old growth restoration. Ecography 36:499-507. 
Schuster, R., T. G. Martin, and P. Arcese. 2014. Bird community conservation and carbon offsets in Western North America. PLoS ONE 11:e99292.

Selinske, M. J., J. Coetzee, K. Purnell, and A. T. Knight. 2015. Understanding the Motivations, Satisfaction, and Retention of Landowners in Private Land Conservation Programs. Conservation Letters:n/a-n/a.

Smith, A. H. 2009. Conservation Easement Violated: What Next-A Discussion of Remedies. Fordham Envtl. L. Rev. 20:597.

Turner, N. J. 2014. Ancient Pathways, Ancestral Knowledge: Ethnobotany and Ecological Wisdom of Indigenous Peoples of Northwestern North America. 2 vol. McGill Queen's University Press, Montreal.

Wilson, K., E. C. Underwood, S. a Morrison, K. R. Klausmeyer, W. W. Murdoch, B. Reyers, G. Wardell-Johnson, P. a Marquet, P. W. Rundel, M. F. McBride, R. L. Pressey, M. Bode, J. M. Hoekstra, S. Andelman, M. Looker, C. Rondinini, P. Kareiva, M. R. Shaw, and H. P. Possingham. 2007. Conserving biodiversity efficiently: what to do, where, and when. PLoS biology 5:e223.

Winter, S. J., K. J. Esler, and M. Kidd. 2005. An index to measure the conservation attitudes of landowners towards Overberg Coastal Renosterveld, a critically endangered vegetation type in the Cape Floral Kingdom, South Africa. Biological Conservation 126:383-394.

Wunder, S. 2007. The efficiency of payments for environmental services in tropical conservation. Conservation biology 21:48-58. 


\section{Table $\mathbf{1}$ (on next page)}

Easement cost estimates

Easement cost estimates from The Nature Trust of British Columbia and Islands Trust Fund. All variable costs follow a saturating curve in the form of: cost $=$ Intercept + Slope $*$ In(easement size [acres]), with the constraint that the cost cannot fall below the minimum. 
Cost $[\$]$

\begin{tabular}{ll}
\hline $\begin{array}{l}\text { Fixed costs } \\
\text { Land owner } \\
\text { legal cost }\end{array}$ & 300 \\
financial advice & 300 \\
Covenant registration & 200 \\
Endowment & 10000 \\
Covenant holder & \\
$\quad$ legal cost & 4000 \\
\hline $\begin{array}{l}\text { Variable costs (by easement size) } \\
\text { Ecological baseline (minimum \$1000) }\end{array}$ & Cost $=2185+1957 * \log ($ easement size in acres) \\
$\begin{array}{l}\text { Appraisal (minimum \$1500) } \\
\text { Land survey (minimum } \$ 1000)\end{array}$ & Cost $=0+1957 * \log ($ easement size in acres) \\
\hline Reoccurring costs (yearly) & \\
Covenant monitoring & 758 \\
Staff cost to reply to Land owner request & 151.6 \\
\hline
\end{tabular}

1 


\section{Table 2 (on next page)}

Main results summary

Summary of the main results related to cost and biodiversity loss. Presented are the mean values with min - max range in brackets. Biodiversity loss values are calculated from the initially protected biodiversity values, i.e. those values represent $100 \%$. 


\begin{tabular}{lrlrl} 
& \multicolumn{2}{c}{ Cost [Million \$] } & \multicolumn{2}{c}{ Biodiversity loss [\%] } \\
\hline Baseline: Land purchase cost (15\% in trust added) & 457 & $(441-470)$ & 0 & \\
Easement setup cost & 44 & $(43-45)$ & 0 & \\
Easement cost after 100 years with no disputes & 162 & $(157-166)$ & 0 & \\
Low dispute rate (0.028\% of easements/year) & $162(157-167)$ & $0.4 \quad(0.1-0.8)$ \\
Medium dispute rate (0.28\% of easements/year) & $180(173-189)$ & $3.7 \quad(2.2-5.2)$ \\
High dispute rate (2.8\% of easement/year) & $355(339-382)$ & $31.7 \quad(28.9-36.1)$ \\
\hline
\end{tabular}
1 


\section{1}

Cost and biodiversity loss comparisons

a) Conservation network cost comparison between land acquisition and conservation easements of varying dispute rates. b) Biodiversity loss of varying easement dispute rates in conservation networks and an initial 20\% protection level of current biodiversity in the CDF ecological zone. Solid lines represent mean values for each approach, and the corresponding ribbons show minimum and maximum values for the 100 Marxan solutions.
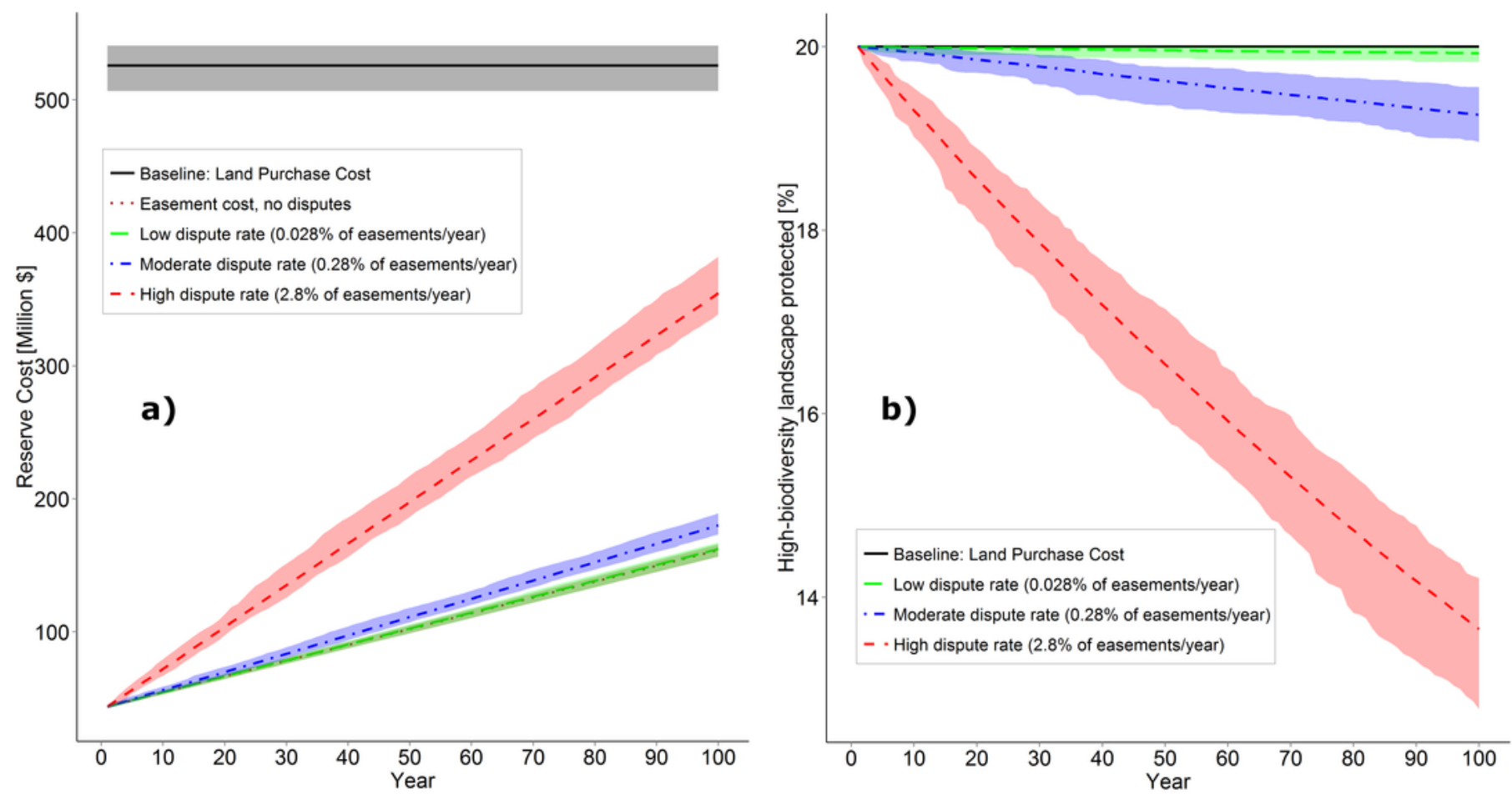
2

Conservation Easement cost effectiveness

Long term cost effectiveness defined as rate of biodiversity protected divided by the reserve network cost. Values are relative to the baseline land purchase scenario. Solid lines represent mean values for each scenario, and the corresponding ribbons show minimum and maximum values for the 100 Marxan solutions. 


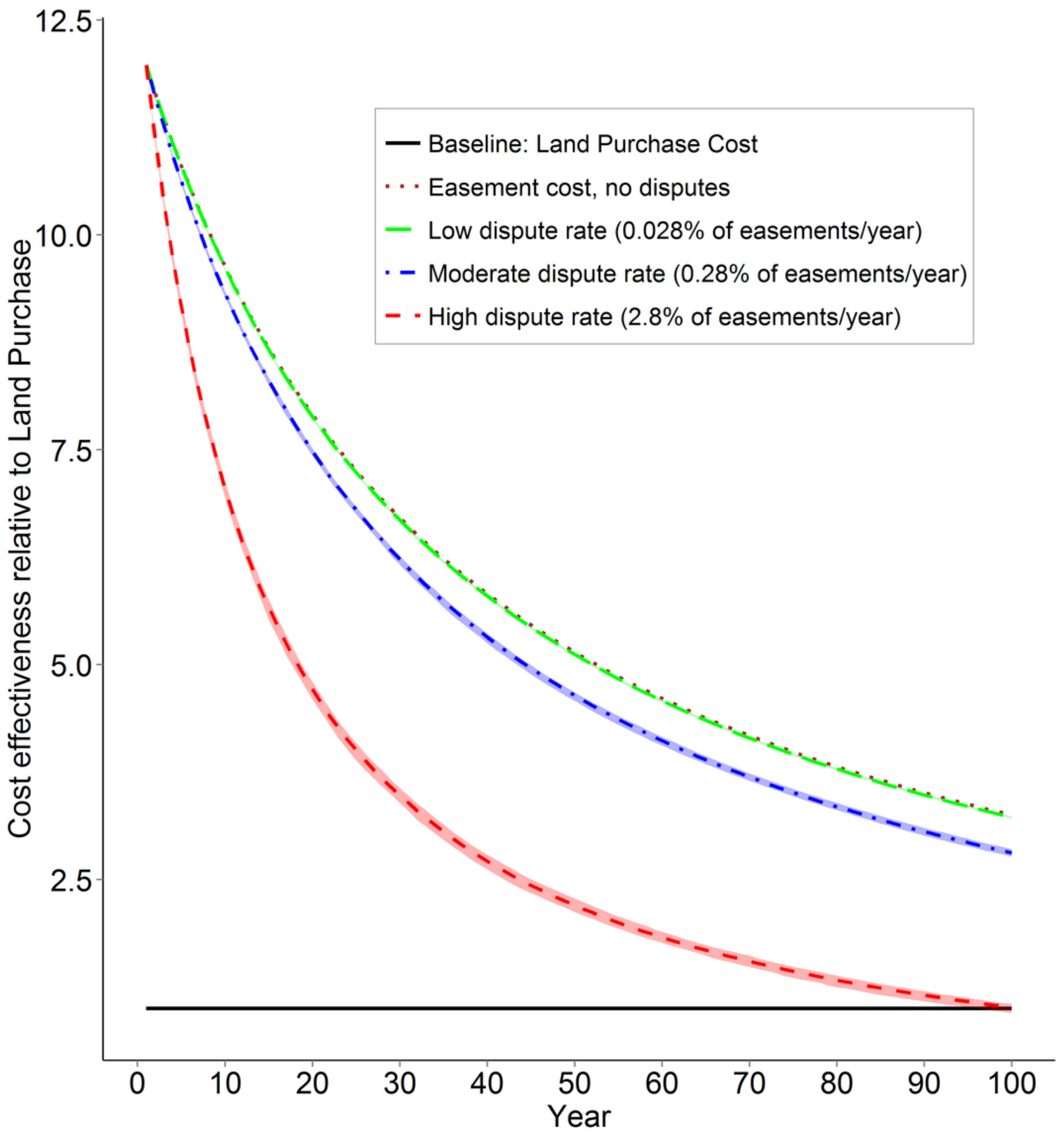

